\title{
Stem volume equation for constructing local volume table of Pinus merkusii Jungh et de Vriese in Tana Toraja community forest
}

\author{
Melewanto Patabang ${ }^{1 *}$, Hardjanto ${ }^{2}$ \\ ${ }^{1}$ Department of Ecotourism, College of Vocational Studies, Institut Pertanian Bogor University \\ Jl. Kumbang No. 14 Babakan, Campus IPB Cilibende, Bogor, Indonesia. 16151 \\ *Email: melewanto@yahoo.co.id \\ ${ }^{2}$ Department of Forest Management, Faculty of Forestry, Institut Pertanian Bogor University \\ Jl. Ulin Lingkar Akademik, Campus IPB Dramaga, Bogor, Indonesia. 16680
}

\begin{abstract}
Pinus merkusii Jungh et de Vriese is a plant with high market and economic values due to providing a variety of products, including wood. Good management is needed to preserve pine forest products. The first step toward effective forest management is developing a management plan based on estimated stock data. The volume table used has a significant impact on the accuracy of the stock potential estimate. This study aims to determine the best equation model for compiling a local volume table for $P$. merkusii Jungh et de Vriese in Tana Toraja Regency. The research was conducted at the community pine forest in Gandang Batu Sillanan and Mengkendek districts, Toraja Regency. The number of sample measured was 100 trees. An analytical method was used to calculate the amount of tree volume on allometric equations. The equation for the stem volume was made using the allometric equation. The research results showed that diameters' mean, standard deviation, and sampling error values were $28.34 \mathrm{~cm}$, $7.39 \mathrm{~cm}$, and 1.45 , respectively, heights were $23.77 \mathrm{~m}, 7.37 \mathrm{~m}$, and 1.44 ; volume was $1.44 \mathrm{~m}^{3}, 0.96 \mathrm{~m}^{3}$, and 0.19. The regression equation modelling showed that the best equation model for estimating volume $P$. merkusii Jungh et de Vriese based on height and diameter was $V=a D^{2} H$.
\end{abstract}

Keywords: allometric equation; forest management; local volume table; pine of South Sulawesi; stem volume

Article History: Received 21 July 2021; Received in revised form 4 August 2021; Accepted 14 November 2021; Available online 30 December 2021

How to Cite This Article: Patabang M, Hardjanto H. 2021. Stem volume equation for constructing local volume table of Pinus merkusii Jungh et de Vriese in Tana Toraja community forest. Biogenesis: Jurnal Ilmiah Biologi. vol 9(2): 137-145. doi: https://doi.org/10.24252/bio.v9i2.22281.

\section{INTRODUCTION}

Pine (Pinus merkusii Jungh et de Vriese) is a popular plant that plays an important role in Indonesia (Sadili, 2015). Pine is a marketable and economically valuable tree species due to the numerous products, such as wood and pine sap (Rusdiana \& Amalia, 2012). Owing to the high commercial value of pine, it is widely planted in a variety of land uses, such as on Sulawesi Island (Imanuddin et al., 2020). According to Cahyono (2011) \& Sallata (2013), pine has durable class IV and strong class V wood, and is the only species that grows naturally in Indonesia, including Tana Toraja Regency. Our previous studies (Hardjanto \& Patabang, 2019) in Tana Toraja indicates that community forests cover an area of 12510 ha in the Tana Toraja, with the largest pine area being 2702 ha in the Mengkendek District.

The Pine forest in Tana Toraja's community forest exists as a result of reforestation efforts initiated in the 1940s by
South Sulawesi Province's forestry officers (Sallata, 2013). Since 2002, the utilization of pine wood from community forests in Tana Toraja as an industrial raw material has begun (Patabang et al., 2014). The production of wood from community forests is becoming a more important component of efforts to meet community wood needs, as the production of jungle wood from natural forests continues to decline. Meanwhile, the community pine forest in Tana Toraja has been expanding as a source of wood (Patabang et al., 2011). To preserve pine forest products, prudent management is required. Without proper management, fluctuations in the value of pine have the potential to result in the extinction of pine trees in a relatively short period of time (Trivena et al., 2019).

The first step toward effective forest management is the development of a management plan based on available data on potential standing stocks (Shrestha et al., 2018). 
Forest potential inventories can be used to determine the current potential standing stock. The inventory of forest potential is the most critical component of forest planning activities, as the data inventory results serve as the primary basis for forest utilization (Abdurachman, 2012). Volume tables are one of the methods used to implement a forest potential inventory. Volume tables are used to predict the volume of standing trees during the forest inventory process (Shrestha et al., 2018). Volume tables are created based on the stem volume's estimated value (Kang et al., 2014). According to Liu et al. (2019) volume estimation is a very important part of forest management. Estimation of stem volume is necessary for sustainable forest resource planning (Islam \& Ullah, 2017). One of the main challenges in forest management is the ability to predict the stem volume of trees accurately and quickly (Soares et al., 2011). Stem volume is obtained from modeling in the form of a regression equation which states the relationship between volume and tree diameter and height (Kang et al., 2014; Shrestha et al., 2018). Modeling the volume equation of a tree can be accomplished using linear, exponential, logarithmic, quadratic, or cubic regression equations (Gonzalez-Benecke et al., 2014; Krisnawati, 2016; Islam \& Ullah, 2017; Mbangilwa \& Jiang, 2019). According to Özçelik \& Göçeri (2015), among the various ways to predict tree volume, the modeling method with regression equations is the most accurate approach.

The linear regression equation modelling is the relationship between the volume components as the independent variable, while the diameter and height as the independent variable. Estimating tree volume using linear regression has provided more accurate results than nonlinear regression (Diamantopoulou et al., 2018). Numerous previous researchers have also used this linear regression equation model, with varying results. Mbangilwa \& Jiang (2019) stated that the optimal volume equation model is determined by the tree's species and the ecology in which it grows. The relationship between diameter and height and tree volume is always different for each tree species
(Wahyudi, 2016). Gonzalez-Benecke et al. (2014) showed that the tree height component had a significant effect on volume, while Lee $e t$ al. (2017) explained that a combination model of diameter and height is the best model for predicting tree volume. On the other hand, Krisnawati (2016) confirmed that the best model is a logarithmic model. The results of regression equation modeling between tree components in the form of diameter, height, and volume were used to compile volume tables in a variety of countries, including Indonesia, Malaysia, China, Pakistan, and Turkey (Abdurachman, 2012; Kang et al., 2014; Shrestha et al., 2018; Kitikidou et al., 2017; Aman \& Ismail, 2020). This study aims to determine the best equation model for compiling the volume table of pine in Tana Toraja Regency. The development of stem volume equations can support more effective forest management. The use of the volume table developed in this study will allow for a reduction in the time and cost of forest inventory, as well as the avoidance of damage to forest stands during the inventory's implementation, as destructive methods will be avoided.

\section{MATERIALS AND METHODS}

Data collection. Data collection was carried out on Pinus merkusii Jungh et de Vriese's stands using non-destructive sampling. The method of selecting samples was carried out using purposive sampling considering the distribution of tree diameters. The location for data collection was carried out in Mengkendek and Gandang Batu Sillanan District, Tana Toraja Regency, as shown in Fig. 1. This location was selected since it retains a fairly large pine forest with the same biophysical condition. The study location is between $3^{\circ} 7^{\prime}-$ $3^{\circ} 17^{\prime}$ south latitude and $113^{\circ}-120^{\circ}$ east longitude, altitude 974-980 masl, temperature $20^{\circ} \mathrm{C}-23^{\circ} \mathrm{C}$, humidity $76-88 \%$, and the number of precipitation $1500-3000 \mathrm{~mm}$ per year. The number of sample trees measured was 100 . According to Leão et al. (2021), the minimum number of samples that can be used to construct volume allometric equations based on height and diameter is 29-39 trees samples. The 
dimensions of the trees measured included diameter at breast height level (dbh), diameter at the base of the section, diameter at the end of the section, length of the section, and tree height. The diameter and volume referred to in this study are the diameter and volume of wood, including bark (diameter and volume over bark). The diameter of the base and end of the section was measured using a maximum length of $5 \mathrm{~m}$ to the end diameter of $6 \mathrm{~cm}$. The diameter and volume referred to in this study are the diameter and volume of wood, including bark (diameter and volume over bark).

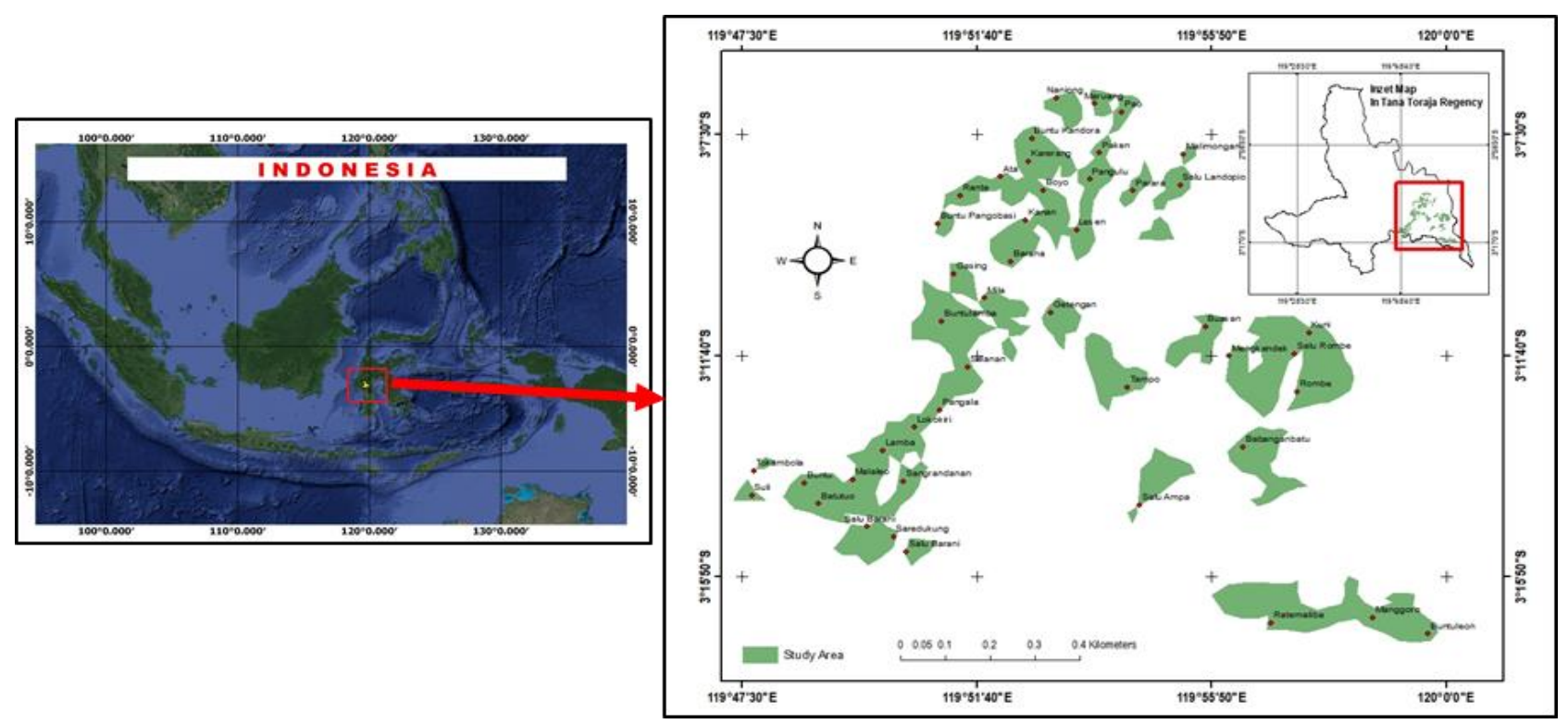

Fig. 1. Research location is in the districts of Mengkendek and Gandang Batu Sillanan, Tana Toraja Regency.

Data analysis. Data analysis was performed by calculating tree volume based on the measurement results of diameter, section length, and tree height. The volume of the tree is calculated using the Smalian equation using equation 1 . Other researchers have previously used this equation to calculate tree volume in forestry, including Soares et al. (2011), Abdurachman (2012), de León \& Valencia (2013), Wahyudi (2016), Fernández et al. (2017), García-Espinoza et al. (2018), Akpo et al. (2020), Aman \& Ismail (2020), Coelho et al. (2021), and Islam et al. (2021).

$V=\frac{L}{2} \times\left(B_{t i}+B_{b i}\right)$

Note: $\mathrm{V}=$ stem volume; $\mathrm{L}=$ length of the section $(\mathrm{m}) ; \mathrm{B}_{\mathrm{ti}}=$ the basal area of the large end of the section $\left(\mathrm{m}^{2}\right) \mathrm{i}^{\text {th }} ; \mathrm{B}_{\mathrm{bi}}=$ the basal area of the small end of the section $\left(\mathrm{m}^{2}\right) \mathrm{i}^{\text {th }}$.

Further analysis for tree volume was carried out using a regression equation to determine the relationship between tree diameter and height and volume. The regression equation used in this study consisted of diameter at breast height level and total height as the independent variable and volume as the dependent variable. Other researchers have previously used this equation to model tree volume in forestry, including Xia et al. (2013), Mate et al. (2015), Moulinier et al. (2015), Krisnawati (2016), Islam \& Ullah (2017), Lee et al. (2017), Shrestha et al. (2018), Cañadas-López et al. (2019), and Mbangilwa \& Jiang (2019). The volume equation used is equation 2 to equation 9 as follows:

$V=a D^{b}$

$V=a+b D^{2}$

$V=a D+b D^{2}$

$V=a+b D+c D^{2}$

$V=a D^{b} H^{c}$

$V=a D^{2} H$

$V=a+b D^{2} H$

$V=a+b H+c D+d D^{2}+e D^{2} H+f D H$

Note: $\mathrm{V}=$ volume $\left(\mathrm{m}^{3}\right) ; \mathrm{D}=$ diameter at breast height level $(\mathrm{cm}) ; \mathrm{H}=$ height (m); a, b, c, d are parameters to be estimated in this study.

Validation is carried out to select the best equation model that can be used in compiling volume tables. Selection of the best model is carried out by calculating the value of the 
coefficient of determination $\left(\mathrm{R}^{2}\right)$, coefficient of determination adjust ( $\mathrm{R}^{2}$ adj.), t-test, root means square error (RMSE), mean deviation (MD), and mean absolute deviation (MAD) (Xia et al., 2013; Gonzalez-Benecke et al., 2014; Lee et al., 2017; Cañadas-López et al., 2019; Hernández et al., 2019; Maltamo et al., 2019; Saarinen et al., 2019; Brūmelis et al., 2020; Marzulli et al., 2020; Socha et al., 2020). This value is calculated as follows, using equations 10 to 15 :

$$
\begin{aligned}
& R^{2}=1-\left[\sum_{i=1}^{n}\left(V_{i}-\widehat{V}_{i}\right)^{2} / \sum_{i=1}^{n}\left(V_{i}-\bar{V}_{i}\right)^{2}\right] \\
& R_{a d j}^{2}=1-\left(1-R^{2}\right)\left[\frac{n-1}{n-(k+1)}\right] \\
& \mathrm{t}=\frac{b_{i}}{S E_{b i}} \\
& R M S E=\sqrt{\sum_{i=1}^{n}\left(V_{i}-\hat{V}_{i}\right)^{2} / n} \\
& M D=\sum_{i=1}^{n}\left(V_{i}-\widehat{V}_{i}\right) / n
\end{aligned}
$$

$M A D=\sum_{i=1}^{n}\left|V_{i}-\hat{V}_{i}\right| / n$

Note: $\mathrm{Vi}=$ measured volume for the $\mathrm{i}^{\text {th }}$ tree; $\hat{V}_{i}=$ predicted volume for the $\mathrm{i}^{\text {th }}$ tree; $\bar{V}=$ measured mean tree volume; $\mathrm{n}=$ the total number of trees; $k=$ the number of independent variables in the regression equation; $\mathrm{b}=$ coefficient regression; $\mathrm{SE}=$ sampling error.

The volume estimate can be calculated using the best equation obtained and then presented in tabular form known as the volume table. Other researchers have used this method of compiling volume tables, including Abdurachman (2012), Aman \& Ismail (2020), Kang et al. (2014), Shrestha et al. (2018), and Kitikidou et al. (2017).

\section{RESULTS AND DISCUSSION}

Table 1 summarizes the measurement findings for diameter, height, and volume that were derived using the Smalian equation (Equation 1).

Table 1. Descriptive statistic of tree samples.

\begin{tabular}{lllllll}
\hline & No. of trees & Mean & Minimum & Maximum & SD & Sampling Error \\
\hline DBH $(\mathrm{cm})$ & 100 & 28.34 & 16.90 & 43.00 & 7.39 & 1.45 \\
Height $(\mathrm{m})$ & 100 & 23.77 & 12.14 & 33.00 & 7.37 & 1.44 \\
Volume $\left(\mathrm{m}^{3}\right)$ & 100 & 1.44 & 0.22 & 3.83 & 0.96 & 0.19 \\
\hline
\end{tabular}

According to Table 1, the mean, standard deviation, and sample error values for diameter are $28.34 \mathrm{~cm}, 7.39 \mathrm{~cm}, 1.45 \mathrm{~cm}$, respectively, height $23.77 \mathrm{~m}, 7.37 \mathrm{~m}$, and 1.44 , respectively, volume $1.44 \mathrm{~m}^{3}, 0.96 \mathrm{~m}^{3}$, and 0.19 , respectively.

These findings suggest that using the Smalian equation to compute volume is quite accurate, as it yields a sampling error value of 0.19 , which is lower than the results of Fernández et al. (2017). The larger the number of samples, according to de León \& Valencia
(2013), the more accurate the findings of measurements using the Smalian equation will be. The maximum number of errors utilizing the Smalian formula for $\mathrm{n}=30$ is $5 \%$, and this error value will decrease as the number of samples investigated increases. The Smalian approach is one that is frequently used in studies to calculate tree volume (Coelho et al., 2021). García-Espinoza et al. (2018) used the Smalian approach to calculate the volume of trees used to construct the volume equation.

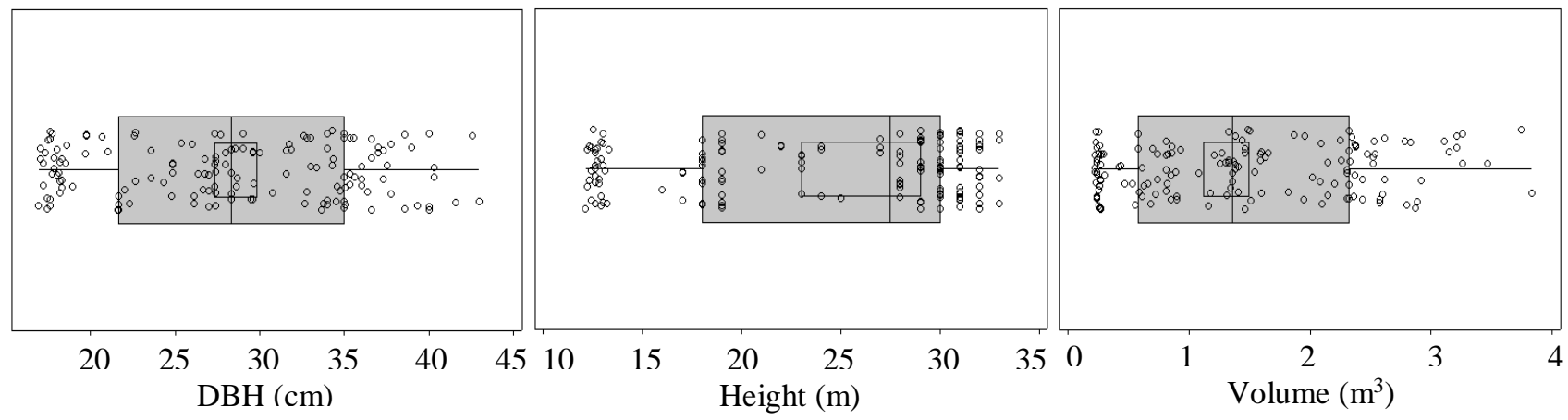

Fig. 2. Data distribution of diameter, height, and volume of samples. 
As illustrated in Fig. 2, the distribution patterns of diameter, height, and volume all differ. The distribution of diameter and volume data is more evenly distributed across all sizes, but the distribution of height data is more concentrated on a certain number of measurement. The data from the measurements and calculations are then utilized to generate a regression equation model based on equations 2 to 9 and the results were represented in Table 2.

Table 2. Description of the regression model for estimating volume Pinus merkusii Jungh et de Vriese in the study area.

\begin{tabular}{|c|c|c|c|c|c|c|c|c|}
\hline \multirow{2}{*}{ Equation } & \multicolumn{6}{|l|}{ Parameters } & \multirow{2}{*}{$\mathrm{F}$} & \multirow{2}{*}{ Sig. } \\
\hline & a & $\mathrm{b}$ & $\mathrm{c}$ & d & e & $\mathrm{f}$ & & \\
\hline$V=a D^{b}$ & $3.66 \mathrm{E}-5$ & 3.104 & & & & & 3516.804 & 0.000 \\
\hline$V=a+b D^{2}$ & -0.492 & 0.002 & & & & & 3102.466 & 0.000 \\
\hline$V=a D+b D^{2}$ & -0.037 & 0.003 & & & & & 5412.402 & 0.000 \\
\hline$V=a+b D+c D^{2}$ & 0.144 & -0.048 & 0.003 & & & & 1609.277 & 0.000 \\
\hline$V=a D^{b} H^{c}$ & $6,26 \mathrm{E}-5$ & 1.982 & 1.020 & & & & 108905.287 & 0.000 \\
\hline$V=a D^{2} H$ & $6.277 \mathrm{E}-5$ & & & & & & 1764417.860 & 0.000 \\
\hline$V=a+b D^{2} H$ & -0.002 & $6.284 \mathrm{E}-5$ & & & & & 543454.719 & 0.000 \\
\hline $\begin{aligned} V= & a+b H+ \\
& c+d D^{2}+e D^{2} H+f D H\end{aligned}$ & 0.130 & -0.004 & -0.011 & 0.001 & $5.619 \mathrm{E}-5$ & 0.001 & 110045.459 & 0.000 \\
\hline
\end{tabular}

In general, the equation model in Table 2 can be classified into two categories according to the independent variables. The first category includes equations in which diameter is the independent variable $(\mathrm{V}=\mathrm{f}[\mathrm{DBH}])$ and equations in which diameter and height are both independent variables $(\mathrm{V}=\mathrm{f}[\mathrm{DBH}$, Height $]$ ).

Table 3. Validation of regression equation model.

\begin{tabular}{lllll}
\hline \multirow{2}{*}{ Equation } & Fit Statistic & & & \\
& $\mathrm{R}_{\text {adj }}^{2}$ & RMSE & MD & MAD \\
\hline$V=a D^{b}$ & 0.960 & 0.2245 & -0.0016 & 0.1666 \\
$V=a+b D^{2}$ & 0.954 & 0.3128 & 0.2130 & 0.2654 \\
$V=a D+b D^{2}$ & 0.987 & 0.2226 & -0.0878 & 0.1512 \\
$V=a D+b D+c D^{2}$ & 0.987 & 0.2186 & 0.0800 & 0.1714 \\
$V=a D^{b} H^{c}$ & 0.999 & 0.0396 & -0.0320 & 0.0320 \\
$V=a D^{2} H$ & 0.999 & 0.0008 & 0.0007 & 0.0007 \\
$V=a+b D^{2} H$ & 0.999 & 0.0012 & 0.0011 & 0.0011 \\
$V=a+b H+c D+d D^{2}+e D^{2} H+f D H$ & 0.999 & 0.3557 & -0.3532 & 0.3532 \\
\hline
\end{tabular}

The results of the $F$ value calculation in Table 2 indicate that there is a significant difference in the value between the first and second category equations. This demonstrates that adding a high component to the equation has an effect on the F value increase. The results of the study in Table 2 indicate that all models have a significant value less than $0.05(\mathrm{P}<0.05)$. As a result, all models are capable of predicting volume values. However, subsequent testing ( $\mathrm{t}-$ test) reveal that there is a variable component in equation 9 that has no significant effect $(\mathrm{P}>0.05)$. The t-test findings in equation 9 indicate that the four independent variables have no significant effect $(\mathrm{P}>0.05)$ and that only the independent variables have a significant effect $(\mathrm{P}<0.05)$. This equation 9 is invalid for estimating the volume of trees. Table 3 details the results of the calculation of these values.

Table 3 shows that the results of statistical test indicate the equations 7 and 8 are the most acceptable for use in this study. The smallest RMSE, MD, and MAD values demonstrate it. According to Lee et al. (2017) and Mate et al. (2015), the optimal model for estimating volume is equation 8 . However, the t-test findings indicate that this equation's constant value has no significant influence $(\mathrm{P}>0.05)$, indicating that equation model 7 is the best. This is also demonstrated by the fact that equation 7 has the minimum RMSE, MD, and MAD values. 

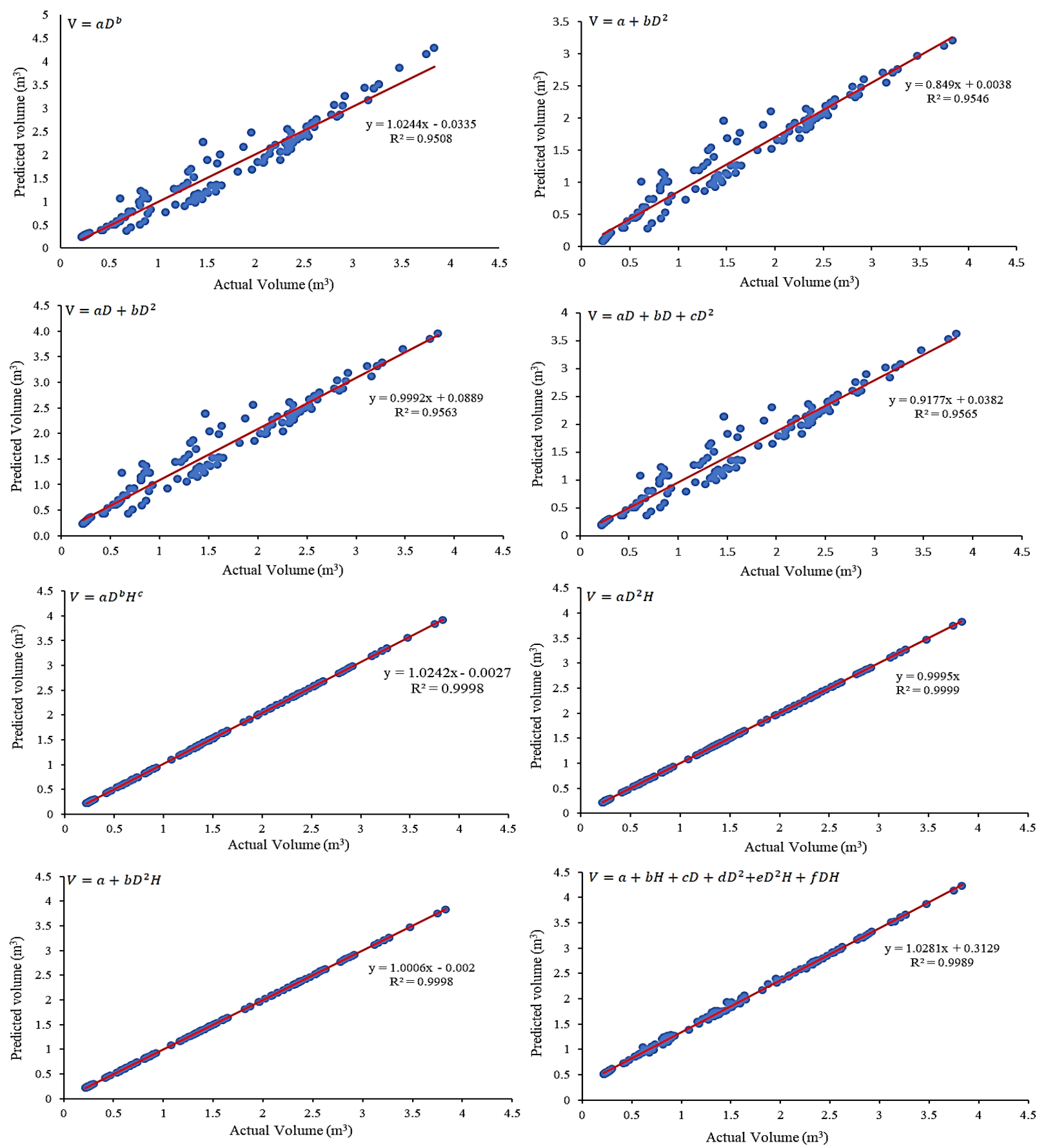

Fig. 3. Relationship between actual and predicted volume.

According to Maltamo et al. (2019) and Saarinen et al. (2019), the best model can be identified by its lowest RMSE. The findings of this study corroborate Islam \& Ullah (2017) assertion that equation 7 is the optimal model for estimating volume based on tree diameter and height. The equations developed as a result of this research are expected to make a significant contribution to the development of tools for forest inventory implementation. Forest managers can use this equation to estimate the standing stocks of pine stand forest. This equation is valid in locations with similar environmental conditions to the research area, but not in areas with significantly different environmental conditions. Environmental factors were not included in the equation as a factor affecting tree growth in this study. Further research is required in a different location with a varied climate, soil type, and nutrient availability. 
Table 4. Local volume table $\left(\mathrm{m}^{3}\right)$ of Pinus merkusii Jungh et de Vriese in research location.

\begin{tabular}{|c|c|c|c|c|c|c|c|c|c|c|c|c|c|c|}
\hline \multirow{2}{*}{$\begin{array}{l}\text { Diam. } \\
\text { (cm) }\end{array}$} & \multicolumn{14}{|c|}{ Height (m) } \\
\hline & 8 & 10 & 12 & 14 & 16 & 18 & 20 & 22 & 24 & 26 & 28 & 30 & 32 & 34 \\
\hline 16 & 0.1286 & 0.1607 & 0.1928 & 0.2250 & 0.2571 & 0.2892 & 0.3214 & 0.3535 & 0.3857 & 0.4178 & 0.4499 & 0.4821 & 0.5142 & 0.5464 \\
\hline 18 & 0.1627 & 0.2034 & 0.2440 & 0.2847 & 0.3254 & 0.3661 & 0.4067 & 0.4474 & 0.4881 & 0.5288 & 0.5694 & 0.6101 & 0.6508 & 0.6915 \\
\hline 20 & 0.2009 & 0.2511 & 0.3013 & 0.3515 & 0.4017 & 0.4519 & 0.5022 & 0.5524 & 0.6026 & 0.6528 & 0.7030 & 0.7532 & 0.8035 & 0.8537 \\
\hline 22 & 0.2430 & 0.3038 & 0.3646 & 0.4253 & 0.4861 & 0.5469 & 0.6076 & 0.6684 & 0.7291 & 0.7899 & 0.8507 & 0.9114 & 0.9722 & 1.0329 \\
\hline 24 & 0.2892 & 0.3616 & 0.4339 & 0.5062 & 0.5785 & 0.6508 & 0.7231 & 0.7954 & 0.8677 & 0.9400 & 1.0124 & 1.0847 & 1.1570 & 1.2293 \\
\hline 26 & 0.3395 & 0.4243 & 0.5092 & 0.5941 & 0.6789 & 0.7638 & 0.8487 & 0.9335 & 1.0184 & 1.1032 & 1.1881 & 1.2730 & 1.3578 & 1.4427 \\
\hline 28 & 0.3937 & 0.4921 & 0.5905 & 0.6890 & 0.7874 & 0.8858 & 0.9842 & 1.0827 & 1.1811 & 1.2795 & 1.3779 & 1.4764 & 1.5748 & 1.6732 \\
\hline 30 & 0.4519 & 0.5649 & 0.6779 & 0.7909 & 0.9039 & 1.0169 & 1.1299 & 1.2428 & 1.3558 & 1.4688 & 1.5818 & 1.6948 & 1.8078 & 1.9208 \\
\hline 32 & 0.5142 & 0.6428 & 0.7713 & 0.8999 & 1.0284 & 1.1570 & 1.2855 & 1.4141 & 1.5426 & 1.6712 & 1.7997 & 1.9283 & 2.0568 & 2.1854 \\
\hline 34 & 0.5805 & 0.7256 & 0.8707 & 1.0159 & 1.1610 & 1.3061 & 1.4512 & 1.5964 & 1.7415 & 1.8866 & 2.0317 & 2.1769 & 2.3220 & 2.4671 \\
\hline 36 & 0.6508 & 0.8135 & 0.9762 & 1.1389 & 1.3016 & 1.4643 & 1.6270 & 1.7897 & 1.9524 & 2.1151 & 2.2778 & 2.4405 & 2.6032 & 2.7659 \\
\hline 38 & 0.7251 & 0.9064 & 1.0877 & 1.2690 & 1.4502 & 1.6315 & 1.8128 & 1.9941 & 2.1754 & 2.3566 & 2.5379 & 2.7192 & 2.9005 & 3.0818 \\
\hline 40 & 0.8035 & 1.0043 & 1.2052 & 1.4060 & 1.6069 & 1.8078 & 2.0086 & 2.2095 & 2.4104 & 2.6112 & 2.8121 & 3.0130 & 3.2138 & 3.4147 \\
\hline 42 & 0.8858 & 1.1073 & 1.3287 & 1.5502 & 1.7716 & 1.9931 & 2.2145 & 2.4360 & 2.6574 & 2.8789 & 3.1003 & 3.3218 & 3.5432 & 3.7647 \\
\hline 44 & 0.9722 & 1.2152 & 1.4583 & 1.7013 & 1.9444 & 2.1874 & 2.4305 & 2.6735 & 2.9165 & 3.1596 & 3.4026 & 3.6457 & 3.8887 & 4.1318 \\
\hline 46 & 1.0626 & 1.3282 & 1.5939 & 1.8595 & 2.1251 & 2.3908 & 2.6564 & 2.9221 & 3.1877 & 3.4534 & 3.7190 & 3.9846 & 4.2503 & 4.5159 \\
\hline 48 & 1.1570 & 1.4462 & 1.7355 & 2.0247 & 2.3140 & 2.6032 & 2.8924 & 3.1817 & 3.4709 & 3.7602 & 4.0494 & 4.3387 & 4.6279 & 4.9172 \\
\hline 50 & 1.2554 & 1.5693 & 1.8831 & 2.1970 & 2.5108 & 2.8247 & 3.1385 & 3.4524 & 3.7662 & 4.0801 & 4.3939 & 4.7078 & 5.0216 & 5.3355 \\
\hline
\end{tabular}

According to Shrestha et al. (2018), the best model can also be determined by the relationship between the predicted and actual volume of trees, as illustrated in Fig. 3. The higher the $\mathrm{R}^{2}$ value, which represents the relationship between the independent and dependent variables, the better, i.e. the larger the $\mathrm{R}^{2}$ value, the better the outcome. The results of the analysis shown in Fig. 3 indicate that equations 6,7 , and 8 produce the best results. Additionally, Fig. 3 demonstrates that equation 7 has the highest $R^{2}$ value. The trend line indicates that equation 6 has an $R^{2}$ value of 0.9999 , and equation 8 has an $\mathrm{R}^{2}$ value of 0.9998. However, in the prior analysis, equation 6 outperforms equations 8. Additionally, Fig. 3 demonstrates that only equation 6 has a direct relationship with actual volume, as it lacks a constant value. The findings of this investigation indicate that equation 7 is an excellent choice for compiling volume tables. Table 4 details the local volume table derived from equation 7 . It will be useful data to prepare a forest management plan based on potential standing stock. The findings of this study can be used to describe the structure, composition, and volume of pine forests, which will aid foresters in gathering accurate data.

\section{CONCLUSION}

The mean, standard deviation, and sampling error values of diameter were 28.34 $\mathrm{cm}, 7.39 \mathrm{~cm}$, and 1.45, respectively, height $23.77 \mathrm{~m}, 7.37 \mathrm{~m}$, and 1.44, respectively, and volume $1.44 \mathrm{~m}^{3}, 0.96 \mathrm{~m}^{3}, 0.19$, respectively. The best equation model for calculating volume based on height and diameter was $V=a D^{2} H$, as determined via regression equation modeling. These findings are the outcome of model validation using statistical testing. This equation can be used as a basis in compiling the local volume table for Pine.

\section{ACKNOWLEDGEMENTS}

The authors thank to the Tana Toraja Regency Government and the Dean of the College of Vocational Studies IPB University for their support in implementing this research.

\section{REFERENCES}

Abdurachman A. 2012. Tabel volume batang di bawah pangkal tajuk pohon keruing (Dipterocarpus acutangulus) di Labanan Berau Kalimantan Timur. Jurnal Penelitian Ekosistem Dipterokarpa. vol 6(1): 31-40. doi: https://doi.org/10.20886/jped.2012.6.1.31-40.

Akpo HA, Atindogbé G, Obiakara MC, Adjinanoukon AB, Gbedolo M, Lejeune P, Fonton NH. 2020. Image data acquisition for estimating individual trees metrics: Closer is better. Forests. vol 11(1): 1- 
15. doi: https://doi.org/10.3390/f11010121.

Aman S, Ismail P. 2020. Construction of local volume table for natural mangroves in Peninsular Malaysia: case study of Sungai Merbok Forest Reserve, Kedah. World Journal of Advanced Research and Reviews. vol 7(2): 264-273. doi: https://doi.org/10.30574/wjarr.2020.7.2.0305.

Brūmelis G, Dauškane I, Elferts D, Strode L, Krama T, Krams I. 2020. Estimates of tree canopy closure and basal area as proxies for tree crown volume at a stand scale. Forests. vol 11(11): 1-9. doi: https://doi.org/10.3390/f11111180.

Cahyono SA. 2011. Faktor-faktor yang mempengaruhi petani menyadap pinus di Kawasan Hutan dengan tujuan khusus (KHDTK) Gombong. Tekno Hutan Tanaman. vol 4(2): 49-56.

Cañadas-López Á, Rade-Loor D, Siegmund-Schultze M, Moreira-Muñoz G, Vargas-Hernández JJ, Wehenkel C. 2019. Growth and yield models for balsa wood plantations in the coastal lowlands of Ecuador. Forests. vol 10(9): 1-16. doi: https://doi.org/10.3390/f10090733.

Coelho J, Fidalgo B, Crisóstomo MM, Salas-González R, Coimbra AP, Mendes M. 2021. Non-destructive fast estimation of tree stem height and volume using image processing. Symmetry. vol 13(3): 1-18. doi: https://doi.org/10.3390/sym13030374.

De León GC, Uranga-Valencia LP. 2013. Theoretical evaluation of Huber and Smalian methods applied to tree stem classical geometries. Bosque.vol 34(3): 311-317. doi: https://doi.org/10.4067/S071792002013000300007.

Diamantopoulou MJ, Özçelik R, Yavuz H. 2018. Treebark volume prediction via machine learning: A case study based on black alder's tree-bark production. Computers and Electronics in Agriculture. vol 151: 431-440. doi: https://doi.org/10.1016/j.compag.2018.06.039.

Fernández MP, Basauri J, Madariaga C, MenéndezMiguélez M, Olea R, Zubizarreta-Gerendiain A. 2017. Effects of thinning and pruning on stem and crown characteristics of radiata pine (Pinus radiata D. Don). iForest-Biogeosciences and Forestry. vol 10(2): 383-390. https://doi.org/10.3832/ifor2037-009.

García-Espinoza GG, Aguirre-Calderón OA, QuiñonezBarraza G, Alanís-Rodríguez E, De Los SantosPosadas HM, García-Magaña JJ. 2018. Taper and volume systems based on ratio equations for Pinus pseudostrobus Lindl. in Mexico. Forests. vol 9(6): 1-14. doi: https://doi.org/10.3390/f9060344.

Gonzalez-Benecke CA, Gezan SA, Samuelson LJ, Cropper Jr WP, Leduc DJ, Martin TA. 2014. Estimating Pinus palustris tree diameter and stem volume from tree height, crown area and stand-level parameters. Journal of Forestry Research. vol 25(1): 43-52. doi: https://doi.org/10.1007/s11676014-0427-4.

Hardjanto H, Patabang M. 2019. Application of the brandis method for yield regulation of pine private forest in Tana Toraja. Jurnal Manajemen Hutan Tropika. vol 25(2): 82-92. doi: https://doi.org/10.7226/jtfm.25.2.82.

Imanuddin R, Hidayat A, Rachmat HH, Turjaman M, Pratiwi P, Nurfatriani F, Indrajaya Y, Susilowati A. 2020. Reforestation and sustainable management of Pinus merkusii forest plantation in Indonesia: A Review. Forests. vol 11(12): 1-22. doi: https://doi.org/10.3390/f11121235.

Islam MR, Azad MS, Mollick AS, Kamruzzaman M, Khan MNI. 2021. Allometric equations for estimating stem biomass of Artocarpus chaplasha Roxb. in Sylhet hill forest of Bangladesh. Trees, Forests and People. vol 4: 1-9. doi: https://doi.org/10.1016/j.tfp.2021.100084.

Islam ZSM, Ullah MR. 2017. Allometric relationships for estimating stem volume of rubber tree (Hevea brasiliensis muell-arg.) in Bangladesh. Open Access Journal of Science. vol 1(1): 17-21. doi: https://doi.org/10.15406/oajs.2017.01.00006.

Kang JT, Son YM, Kim SW, Lee SJ, Park H. 2014. Development of local stem volume table for Pinus densiflora $\mathrm{S}$. et $\mathrm{Z}$. using tree stem taper model. Korean Journal of Agricultural and Forest Meteorology. vol 16(4): 327-335. doi: https://doi.org/10.5532/KJAFM.2014.16.4.327.

Kitikidou K, Milios E, Radoglou K. 2017. Single-entry volume table for Pinus brutia in a planted periurban forest. Annals of Silvicultural Research. vol 41(2): 74-79. doi: http://dx.doi.org/ 10.12899/asr1437.

Krisnawati H. 2016. Compatible estimation model of stem volume and taper for Acacia mangium Willd. plantations. Indonesian Journal of Forestry Research. vol 3(1): 49-64. doi: https://doi.org/10.20886/ijfr.2016.3.1.49-64.

Leão FM, Nascimento RGM, Emmert F, Santos GGA, Caldeira NAM, Miranda IS. 2021. How many trees are necessary to fit an accurate volume model for the Amazon forest? A site-dependent analysis. Forest Ecology and Management. vol 480: 1-10. doi: https://doi.org/10.1016/j.foreco.2020.118652.

Lee D, Seo Y, Choi J. 2017. Estimation and validation of stem volume equations for Pinus densiflora, Pinus koraiensis, and Larix kaempferi in South Korea. Forest Science and Technology. vol 13(2): 77-82. doi: https://doi.org/10.1080/21580103.2017.1315963.

Liu J, Wang X, Wang T. 2019. Classification of tree species and stock volume estimation in ground forest images using deep learning. Computers and Electronics in Agriculture. vol 166: 1-10. doi: https://doi.org/10.1016/j.compag.2019.105012.

Maltamo M, Hauglin M, Næsset E, Gobakken T. 2019. Estimating stand level stem diameter distribution utilizing harvester data and airborne laser scanning. Silva Fennica. vol 53(3): 1-19. doi: http://dx.doi.org/10.14214/sf.10075.

Marzulli MI, Raumonen P, Greco R, Persia M, Tartarino P. 2020. Estimating tree stem diameters and volume 
from smartphone photogrammetric point clouds. Forestry: An International Journal of Forest Research. vol 93(3): 411-429. doi: https://doi.org/10.1093/forestry/cpz067.

Mate R, Johansson T, Sitoe A. 2015. Stem volume equations for valuable timber species in Mozambique. Journal of Sustainable Forestry. vol 34(8): 787-806. doi: https://doi.org/10.1080/10549811.2015.1039043.

Mbangilwa MM, Jiang LC. 2019. Evaluation of region and subregion-based total volume equations for Dahurian larch in northeast China. Applied Ecology and Environmental Research. vol 17(5): 1054310564.

doi: http://dx.doi.org/10.15666/aeer/1705_1054310564.

Moulinier J, Brais S, Harvey BD, Koubaa A. 2015. Response of boreal jack pine (Pinus banksiana Lamb.) stands to a gradient of commercial thinning intensities, with and without $\mathrm{N}$ fertilization. Forests. vol 6(8): 2678-2702. doi: https://doi.org/10.3390/f6082678.

Özçelik R, Göçeri MF. 2015. Compatible merchantable stem volume and taper equations for eucalyptus plantations in the Eastern Mediterranean Region of Turkey. Turkish Journal of Agriculture and Forestry. vol 39(6): 851-863. doi: https://doi.org/10.3906/tar-1501-27.

Patabang M, Malamassam D, Paembonan SA, Dassir M. 2011. Model prediksi riap tinggi jenis pinus (Pinus merkusii) pada Hutan Rakyat di Tana Toraja. Jurnal Hutan dan Masyarakat. vol 6(2): 111-115.

Patabang M, Malamassam D, Hardjanto H. 2014. Growth model of pine (Pinus merkusii Jungh. Et de Vriese) stand on community forest in Tana Toraja Regency. Jurnal Manajemen Hutan Tropika. vol 20(1): 1-8. doi: https://doi.org/10.7226/jtfm.20.1.1.

Rusdiana O, Amalia RF. 2012. Land suitability of Pinus merkusii Jungh et de Vriese on ex-standing area of Tectona grandis Linn. F. Jurnal Silvikultur Tropika. vol 3(3): 174-181. doi: https://doi.org/10.29244/jsiltrop.3.3.\%25p.

Saarinen N, Kankare V, Pyörälä J, Yrttimaa T, Liang X, Wulder MA, Holopainen M, Hyyppä J, Vastaranta M. 2019. Assessing the effects of sample size on parametrizing a taper curve equation and the resultant stem-volume estimates. Forests. vol 10(10): 1-16. doi: https://doi.org/10.3390/f10100848.

Sadili A. 2015. Autekologi pertumbuhan pinus (Pinus merkusii Junghuhn et de Vriese) paska erupsi di Gunung Galunggung, Kabupaten TasikmalayaJawa Barat. Berita Biologi. vol 14(3): 241-248. doi: http://dx.doi.org/10.14203/beritabiologi.v14i3.182 7.

Sallata MK. 2013. Pinus (Pinus merkusii Jungh et de Vriese) dan keberadaannya di Kabupaten Tana Toraja, Sulawesi Selatan. Buletin Eboni. vol 10(2): 85-98.

doi: https://doi.org/10.20886/buleboni.5013.

Shrestha HL, Kafle MR, Khanal K, Mandal RA, Khanal K. 2018. Developing local volume tables for three important tree species in Nawalparasi and Kapilvastu districts. Banko Janakari. vol 28(4): 84 91.

doi: https://doi.org/10.3126/banko.v27i3.20552.

Soares FAAMN, Flôres EL, Cabacinha CD, Carrijo GA, Veiga ACP. 2011. Recursive diameter prediction and volume calculation of eucalyptus trees using multilayer perceptron networks. Computers and Electronics in Agriculture. vol 78(1): 19-27. doi: https://doi.org/10.1016/j.compag.2011.05.008.

Socha J, Netzel P, Cywicka D. 2020. Stem taper approximation by artificial neural network and a regression set models. Forests. vol 11(1): 1-14. doi: https://doi.org/10.3390/f11010079.

Trivena T, Dassir M, Mujetahid A. 2019. Pine SAP cultivation partnership pattern in the forest management unit of Central Mamasa. Advances in Environmental Biology. vol 13(12): 16-21. doi: https://doi.org/10.22587/aeb.2019.13.12.4.

Wahyudi W. 2016. Tabel volume pohon "Berkhout" pada hutan alam tanah kering di Wilayah Kapuas Hulu, Provinsi Kalimantan Tengah. Jurnal Hutan Tropika. vol 11(1): 53-59. doi: https://doi.org/10.36873/jht.v21i01.52.

Xia ZS, Zeng WS, Zhu S, Luo HZ. 2013. Construction of tree volume equations for Chinese fir plantations in Guizhou Province, southwestern China. Forest Science and Practice. vol 15(3): 179-185. doi: https://doi.org/10.1007/s11632-013-0304-9. 